УДК 618.3-06:618.15-022.7]-07-085

DOI 10.11603/24116-4944.2016.2.6869

\author{
๑ В. Ф. Нагорна, А. А. Гриценко, Т. Я. Москаленко \\ Одесъкий національний медичний університет
}

\title{
ОСОБЛИВОСТІ ДІАГНОСТИКИ ТА ЛІКУВАННЯ БАКВАГІНОЗУ У ВАГІТНИХ
}

ОСОБЛИВОСТІ ДІАГНОСТИКИ ТА ЛІКУВАННЯ БАКВАГІНОЗУ У ВАГІТНИХ. АВТорамИ на підставі обстеження 60 вагітних з баквагінозом наведені значні розбіжності результатів різних діагностичних методів та різна ефективність лікування залежно від етіологічного фактора. Найбільш достовірним визнано вимірювання рН піхвового вмісту та виявлення збудників Gardnerella vaginalis, Atopobium vaginalis за допомогою методів ДНК-технологій. Лікування потребує призначення різних препаратів залежно від етіологічного фрактора.

ОСОБЕННОСТИ ДИАГНОСТИКИ И ЛЕЧЕНИЯ БАКВАГИНОЗА У БЕРЕМЕННЫХ. АВТораМИ на осНоваНИИ обследОВанИЯ 60 беременных с баквагинозом приведены значительные расхождения результатов различных диагностических методов и разная эсрфективность лечения в зависимости от этиологического фрактора. Наиболее достоверным признано измерение рН влагалищного содержимого и выявление возбудителей Gardnerella vaginalis, Atopobium vaginalis с помощью методов ДНК-технологий. Лечение требует назначения различных препаратов в зависимости от этиологического фрактора.

FEATURES OF BACTERIAL VAGINOSIS DIAGNOSIS AND TREATMENT OF PREGNANT WOMEN. The authors based on survey of 60 pregnant women with bacterial vaginosis present significant differences of results of different diagnostic methods and treatment effectiveness varies depending on the etiological factor. The most significant vaginal $\mathrm{pH}$ measurement recognized content and identify pathogens Gardnerella vaginalis, Atopobium vaginalis via DNA technology methods. Treatment requires assignment of different drugs depending on the etiological factor.

Ключові слова: вагітність, баквагіноз, діагностика, лікування.

Ключевые слова: беременность, баквагиноз, диагностика, лечение.

Key words: pregnancy, bacterial vaginosis, diagnostic, treatment.

ВСТУП. Багаторічні дискусії навколо визначення суті баквагінозу, його безпечності або небезпечності, особливо під час вагітності, методів діагностики, обов'язковості чи необов'язковості лікування знайшли конкретні відповіді, але не на всі позиції цієї проблеми. 3 чотирьох типів стану піхвової мікробіоти (нормальний, проміжковий, дисбактеріоз, аеробний вагініт), що відповідають критеріям ВОО3, якими користуються вітчизняні лікарі, баквагіноз відносять до стану піхвового дисбактеріозу, який може бути причиною інфрікування матері та плода, тому жінка потребує лікування. Найбільші труднощі, а тому і помилки, пов'язані з діагностикою баквагінозу. По суті, стан дисбіозу являє собою різке превалювання анаеробної з різким зниженням або відсутністю захисної лактобацилярної фрлори $(1,2)$. Діагностика баквагінозу складається з двох підходів: клінічного та параклінічних, тобто лабораторних. Жоден 3 цих методів не $є$ абсолютно достовірним. Основний метод клінічної діагностики - метод Амселя, що визначає типові скарги (патологічні виділення з піхви, гомогенні з неприємним запахом гнилої риби, позитивний амінний тест 3 $10 \%$ розчином КОН, «ключові клітини» при мікроскопії піхвового мазка, збільшення рН піхвового вмісту більше 4,5). 3 огляду на те, що амінним тестом і вимірюванням $\mathrm{pH}$ нехтують, тест дійсно перетворюється на клінічний (скарги). Але останні спостерігаються далеко не у всіх хворих. «Ключові» клітини мають діагностичну інфрормативність тільки в тому випадку, коли їх вміст у препараті досягає більше 20 \% (3,4), для лікаря-лаборанта їх ідентифрікація досить утруднена.

Лабораторний метод Ньюджента, що ідентифікує 3 бактеріальні морсоотипи: великі Гр (+) палички (лактобацили), невеликі Гр (-) та Гр варіабельні коки й кокобацили
(Gardnerella) і Гр (-) та Гр варіабельні вигнуті палички (Mobiluncus), потім оцінює їх кількість у балах, страждає на суб'єктивність, дуже затратний за часом, напруженням лікаря-лаборанта. Метод Айсон-Хея, що визначає 5 типів мікробіотики, не знайшов застосування. Він не зіставляється 3 клінічним методом Амселя [3]. Культуральний метод для діагностики баквагінозу не використовується. Методи, засновані на критеріях ВООЗ [1], - це цитологічні методи, де підраховують кількість лейкоцитів (іх мало або вони відсутні), та ідентифрікують мікрофрлору (різке зниження лактобацил, змішана фрлора) - ненадійні, бо кількість лейкоцитів при нормоцинозі та проміжковому типі біоценозу теж зовсім низька і залежить від долабораторних та лабораторних помилок. Виходячи з вищезазначеного, найбільш надійною слід вважати діагностику за методом, що ідентифрікує безпосередньо збудників баквагінозу, та слід продовжити пошук методів, найбільш доступних та відповідних методам визначення збудників. При баквагінозі доведено етіологічну роль Gardnerella vag. та Atopobium vag. Роль інших представників поліморфної фрлори, характерної для баквагінозу (Prevotella, Porphyromonas Spp), сумнівна, не доведена в дослідженнях.

Незважаючи на те, що для лікування піхвових інфекцій застосовується багаточисельна група антибіотиків та антисептиків, для хворих та вагітних, що страждають від баквагінозу, препаратом вибору залишаються препарати групи імідазолів, що призначаються перорально, внутрішньопіхвово. Саме вони більш за інших володіють антианаеробною дією.

MАTЕРІАЛИ ТА МЕТОДИ. Клінічну групУ склали 60 вагітних жінок віком від 21 до 41 року в різних термінах вагітності. При обстеженні (якісний бактеріологічний 
метод) у всіх жінок були виявлені Gardnerella vag. або Atopobium vag., що дало можливість ставити діагноз баквагіноз. У 22 жінок після 20 тижнів вагітності за даними УзД доплерометрії діагностовано диссрункцію плаценти, 33 жінки з приводу загрози переривання, дисфункції плаценти, патології прикріплення плаценти, завмерлої вагітності були госпіталізовані. У 5 вагітних був хронічний пієлонефрит у стадії загострення. У трьох вагітність настала після застосування ДРТ. У 58 (96,6 \%) вагітних були ознаки диссункції кишечника. Клінічний аналіз скарг хворих на баквагіноз показав наступне: скарги були різноманітними, але констатували їх тільки 56,6 \% (34) вагітних. Серед вагітних у 35 \% (21) були патологічні виділення з неприємним запахом, відчуття дискомфорту в ділянці зовнішніх статевих органів, піхви та уретри: печія - у 16,6 \% (10), порушення сечовипускання - у 8,4 \% (5). При обстеженні у 36,6 \% (34) вагітних були констатовані значні виділення 3 піхви, у 26,6 \% (16) - у вигляді сірих 3 неприємним запахом слідів на дзеркалі. Ознак запалення на слизових оболонках не знайдено. В роботі використані такі методи дослідження: загальноклінічний (опитування, огляд, фрізикальне, внутрішнє акушерське обстеження); цитологічний (піхвовий мазок за стандартною схемою дослідження); метод з використанням ДНК-технологій: метод мультиплексної ПлР у реальному часі. Застосований метод дозволяє ідентифікувати ті мікроорганізми, що не тільки можуть бути наявними у піхві, а етіологічну роль яких у виникненні інфекції піхви доведено. Метод дозволяє визначити кількісний вміст бактерій взагалі, окремо лактобактерій, трьох видів умовно-патогенних мікоплазм (M.hominis, parvum, urealiticym), збудників баквагінозу анаеробних мікробів (Gardnerella vag., Atopobium vag.), групи аеробних мікробів (Enterobac., Staph spp., Strept. spp), та представників групи NCMT (N. Gonorrhoeae, Chl. trach., Mycopl., Trich. vag. ) - ІПСШ, групи грибів роду Candida (Cand. alb., glabr., krusei., trop., paraps); бактеріологічний метод дослідження піхвового вмісту; визначення pH піхвового вмісту за допомогою тест-смужок.

РЕЗУЛЬТАТИ ДОСЛІДЖЕННЯ ТА ЇХ ОБГОВОРЕНня. Проаналізовані дані отриманих бактеріологічних показників. Збудником баквагінозу у 3,3 \% (2) випадках виявлений Atopobium vag., у 96,6 \% (58) - Gardnerella vag., у 28,3 \% (17) - поєднана фллора - Gardnerella vag. та Atopobium vag., у 11,6 \% (7) - Mobiluncus, Corinebact. разом із Gardnerella vag. та Atopobium vag. Проведено аналіз співвідношення концентрації збудників та значення $\mathrm{pH}$ піхвового вмісту. Констатовано: при $\mathrm{pH}$ 4,0 у жодної жінки не було ідентифріковано збудників баквагінозу; при рН 4,4 - у двох (3,3 \%) виділено Atopobium vag. у незначній концентрації. При рН 4,7 концентрація Gardnerella vag. відмічена від незначної $(\log 3,1)$ до діагностично вагомої (log 5,7), а Atopobium vag. виділено у 6 жінок у низьких концентраціях $(\log 0,2-1,3)$. Клінічні прояви в цій групі були у 5 (8,3 \%) жінок. Більш висока концентрація збудників зареєстрована при $\mathrm{pH} 5,0$ у 21 (35\%) жінки $(\log 5,4-8,5)$, у двох - $\log 0,4-0,7$. Найвища концентрація Gardnerella vag. (Atopobium vag. у 5317 жінок $\log 6,4-8,5)$ відповідала рН більше 5,5. Але саме в цій групі зареєстрована найбільша присутність умовнопатогенної фрлори (Enterobac., Strept. spp) у концентрації $\log 4,0-6,5$. Аналіз рН відносно аеробної фрлори показав, що перевищення концентрації Enterobac. log вище 3,0
(3,0-5,5) відповідає pH 5,0; log вище 4 (4,0-5,5) - pH 5,5 та вище. Аналогічні дані отримані відносно концентрації Staph. spp. - $\log >$ 3,3 відповідає pH 5,0, концентрація Strept. spp. - $\log >4,8(5,0-6,5)$ відповідає pH 5,5 $(5,5-6,5)$.

Зіставлення кількості лейкоцитів у мазках піхви 3 концентрацією анаеробів показало відсутність їх співвідношення. Так, кількості лейкоцитів 0-2-4 у переважаючій більшості випадків (92 \%) відповідає аеробна фрлора $\log >3,3(3,3-6,5)$ і рH 5,0-5,5 та вища; у 8 \% жінок тій же концентрації фрлори відповідало 15-20-40 лейкоцитів. Можна погодитись 3 думкою авторів [4-6], які вважають, що баквагіноз на ранніх стадіях розвитку не демонструє ознаки запалення через пригніченість нейтрофрілів (їх мало, фагоцитоз незавершений). При тривалому перебігу дисбіозу вірогідність розвитку запальної реакції слизових оболонок підвищується у зв'язку з порушенням адаптаційних можливостей $[5,6]$. Треба також наголосити, що при тривалому перебігу до анаеробної фрлори приєднується аеробна і дисбіоз перетворюється на вагініт змішаної етіології. Баквагіноз, за загальним уявленням, супроводжується значним пригніченням лактосрлори, на кількісний вміст якої вказують найбільш вживані цитологічний, бактеріологічний методи та застосований у роботі метод мультиплексної плР у реальному часі. Ми виявили невідповідність даних цих методів за показником кількості лактобакцил. Так, низькому вмісту за методом ДНК-технологій $\log$ 4,35-6,15 тільки у 61,1\% спостережень відповідав низький вміст (25-30 \%) лактобактерій за іншими методами.

Лікування проведено препаратом 3 групи імідазолів внутрішньопіхвово протягом 7 діб (після 16 тижнів вагітності) в комплексі з пробіотиками внутрішньопіхвово та перорально разом з вітаміном C 3-4 доби з початку лікування. Після призначеного курсу суб'єктивне покращення почалося з 3-4 доби лікування. $\mathrm{pH}$ піхвового секрету стабілізувався на значеннях 4,0-4,7 на 6 добу у $68,2 \%$ (41) жінок; у 31,8 \% (19) жінок показник залишався на рівні 5,0-5,5. У цих жінок через 1-4 тижні констатовано рецидив. Саме у цих вагітних за даними ПлР виявлено Atopobium vag. Другий курс лікування проведено жінкам 3 рецидивом деквалінієм хлоридом внутрішньопіхвово поєднано з пробіотиком внутрішньопіхвово протягом 6 діб, ці жінки продовжували приймати пробіотик перорально протягом 1 місяця. На 7 добу показник рН стабілізувався на рівні 4,0-4,4, кількість лейкоцитів у мазках визначалась 5-8 у полі зору. Кількість лактобактерій у 86,6 \% (52) жінок підвищилась до $\log 6,8-\log 7,8$. Контрольне обстеження (ПЛР) через 2 місяці після завершення лікування не виявило збудників баквагінозу (Gardnerella vag., Atopobium vag., Mobiluncus). Стан мікробіоти до завершення вагітності контролювався визначенням $\mathrm{pH}-$ не перевищував 4,7. Ускладнень запального характеру під час пологів та в післяпологовому періоді не було.

ВИСноВКИ. 1. Клінічні ознаки баквагінозу констатовано тільки у 31,6-56,6 \% вагітних із верифрікованим діагнозом.

2. Збудниками баквагінозу виявлено у 3,3\% Atopobium vag. у монокультурі, у 28,3 \% в поєднанні з Gardnerella vaginalis, остання виявлена у $96,7 \%$ жінок.

3. Найбільш діагностично інформативним виявились показники $\mathrm{pH}$ піхвового секрету ( $\mathrm{pH}-4,7)$, та метод застосування ДНК-технологій - метод мультиплексної 
ПлР у реальному часі, який дозволяє ідентифікувати 16-24 збудників та їх кількісний вміст відносно загальної бактеріальної маси. Визначення рН піхвового вмісту повинно використовуватись багаторазово під час вагітності лікарем і самою жінкою.

4. Якщо збудниками баквагінозу є Atopobium vag., застосування стандартної схеми препаратом групи імідазолу внутрішньопіхвово не $є$ есективним.

\section{СПИСОК ЛІТЕРАТУРИ}

1. Кира Е. Ф. Клиника и диагностика бактериального вагиноза / Е. Ф. Кира // Акушерство и гинекология. - 1996. - № 2. - С. 32-35.

2. Радзинский В. Е. Акушерская агрессия / В. Е. Радзинский. - М. : Изд-во журнала Status praesens, 2012. - 672 с.

3. Шейка матки, влагалище, вульва. Физиология, патология, кольпоскопия, эстетическая коррекция : руководство для практикующих врачей / под ред. С. И. Роговской, Е. В. Липовой. - М. : Издательство журнала Status praesens, 2014. -832 c.
ПЕРСПЕКТИВИ ПОДАЛЬШИХ ДОСЛІДЖЕНЬ. Застосований поєднаний метод визначення $\mathrm{pH}$ піхвового вмісту та ДНК-технологій (метод мультиплексної плР у реальному часі) є перспективним методом у своєчасній діагностиці баквагінозу з таким збудником, як Atopobiumvag., а тому подальше вивчення методу може бути використаним у своєчасній діагностиці, індивідуалізації лікування та попередженні ускладнень вагітності.

4. Кира Е. Ф. Бактериальний вагиноз / Е. Ф. Кира. - М. : МИА, 2012. - 472 c.

5. Микробиом и здоровье женщины (обзор литературы) / Д. С. Янковский, В. П. Широбоков, Ю. Г. Антипкин [и др.] // Репродуктивная эндокринология. - 2015. - № 4 (24). C. 13-28.

6. Eschenback D. A. Diagnosis and clinical manifestation of bacterial vaginosis / D. A. Eschenback, S. L. Hiller // Am. G. Obstet. Gynecol. - 2002. - Vol. 158. - P. 819-828.

Отримано 19.05.16 